\title{
Effect of Food Type on Some Biological Aspects Of Monacha Cartusiana (Muller) Snail Under Laboratory Conditions
}

\author{
Arafa, A. A. I \\ Plant Protection Research Institute, Agric. Res, Cent., Dokkii, Giza, Egypt
}

\begin{abstract}
The Effect of different food typs on numbers of clutches, eggs and clutch size as well as growth pattern of Monacha cartusiana snail as indicated by shell diameter and body weight were studied under laboratory conditions. Results revealed that when adults of M. cartusiana snail were fed on leaves of different plant species during the breeding season, numbers of clutches, eggs and clutch size were significantly differed from one plant to another. Regarding general meas, the highest numbers of clutches, eggs and clutch size were recorded with pea leaves with values of $2.66,133.26$ and 48.05 , respectively, while lowest values were obtained with carrot which gave 1.2, 29.06 and 24.03, respectively, during February, 2013.

Regarding, the effect of the tested plant species on growth of M. cartusiana snail, those could be arranged descendingly according to their suitability as follows: pea, lettuce, cabbage, Egyptian clover and carrot leaves.
\end{abstract}

Keywords: Food Type, Biological Aspects, Snail.

\section{Introduction}

Land molluscs have been increased rapidly in the late years and considered as serious pests attack all crops and caused severe damage to all plant parts and subsequently reducing marketing values of these crops (Barker, 2002). The gastropods including snails and slugs are of economic importance to man where they caused several damage in agriculture, horticulture and forestry. In addition, their importance in medical and veterinary practice since they serve as intermediate hosts for certain parasitic worms of man and his domestic animals. Snail and slug pests are essentially vegetarian and feed on a wide variety of plant materials both wild and cultivated which include field, vegetable and fruit crops as well as ornamental plants (Godan, 1983).

In Egypt, up till 1980's it was established that certain land molluscs has been concentrated mostly in northern governorates of Delta region. Gastropods left viscous liquids on the plants giving a bright trace film, since farmers complained that their cattles refused feeding on berseem (Egyptian clover) due to unaccepted glistening slimes of the infested plants making farm animals to refuse eating on these plants (El-Okda 1980). In Sharkia governorate many authors investigated ecological and biological aspects of some land snails as economic pests that cause severe damage on vegetable and field crops (Nakhla and Tadros, 1995,EL-Masry 1997, Ismail 1997, Arafa, 1997, Mahrous et a.l, 2002 and Lokma, 2013).

The effect of food type on fecundity of some land snails was studied by many authors under laboratory conditions at Sharkia governorate (Ismail 1997and Abed 2011). Moreover, the effect of food type on growth as indicated by weight and shell diameter was determined by many investigators in Egypt
(Asran1994, Ismail 1997, Ismail 2004 and Lokma 2007).

The present work aimed to study the effect of different food typs on some biological aspects and growth of $M$. cartusiana during the breeding season.

\section{Material and Methods}

\subsection{Tested animals:}

Subadult snails of $M$. cartusiana less than $12 \mathrm{~mm}$ in shell diameter were collected in March, 2012 from highly infested field cultivated with sugarcane plants at Mymouna village, Meniet El-Kamh district, Sharkia governorate. Collected snails were transferred in plastic bags to the laboratory of Plant Protection Research Institute, Sharkia branch and then placed in glass containers $(50 \times 30 \times 30 \mathrm{~cm})$ and fed on cabbage leaves until they reached maturity.

\subsection{Effect of food type on some biological aspects} of $M$. cartusiana snails under laboratory conditions:

The effect of food types (pea, Pisum sativum, lettuce, Lactuca sativa, cabbage, Brassica oleracea, Egyptian clover, Trifolium alexandrinum and carrot, Daucus catota) was investigated on number of clutches, eggs and clutch size of $M$. cartsiana snails. Clay soil was obtained from sugarcane field at Mymouna village. Twenty five plastic pots of $10-\mathrm{cm}$ diameter (3/4 $\mathrm{kg}$ capacity) were filled with sieved and steam sterilized soil to a depth of about $8 \mathrm{~cm}$. Equal volume of distilled water was added to each plastic pot to keep soil moisture near field capacity (Ismail, 1997). Five replicates were used for each treatment. Each, treatment was supplied with amount of fresh leaves of the mentioned five plant species for feeding. One pair of the snails. adults recognized by 
white end and reddish strip was introduced into each pot. The plastic pots were closed with muslin cloth and secured with rubber bands to prevent snails from escaping and kept at laboratory temperature (ElOkda, 1981).

The old leaves were changed daily and soil remoisted as needed. The soil within each pot was inspected weekly for searching clutches using fine pair of forceps during the period from December, 2012 to February 2013. The clutches were removed carefully and the number of eggs in each clutch was counted. Obtained data were subjected to statistical analysis using $\mathrm{F}$ test and means were separated by Duncan's multiple range test (Duncan's, 1955).

1.3. Effect of feeding on leaves of five plant species on growth parameters of $M$. cartusiana under laboratory conditions:

The effect of food type (pea, lettuce, cabbage, Egyptian clover and carrot) on growth of $M$. cartusiana snails as indicated by shell diameter and weight was determined during the period from Junuary 2013to June 2013 under laboratory conditions. Two newly hatched juveniles of a similar shell size were weighed and introduced into aplastic pot. Five replicates were used in each treatment. Each pot was supplied with two grams of fresh leaves of the different five plant species mentioned previously. Food was introduced daily and soil was remoistened as needed. The posts were closed with muslin cloth and secured with rubber band to prevent snails from escaping and kept at laboratory temperature (El-Okda 1981). Weight (mg) and shell diameter $(\mathrm{mm})$ of each snail were recorded monthly during the period from January to June 2013.

Data were subjected to statistical analysis according to one way analysis of variance (ANOVA) and Duncan's multiple range test of means (Duncan's, 1955).

\section{Results and Discussion}

\section{I- Effect of food type on some biological aspects of $M$. cartusiana snails.}

The effect pea, lettuce, cabbage, Egyptian clover and carrot leaves on numbers of clutches, and eggs and clutch size of $M$. cartusiana snails were studied under laboratory conditions. Data in Table (1) showed that when adults of $M$. cartusiana snails were fed on different plant leaves during the breeding season, the numbers of clutches, eggs and clutch size were significantly differed from one plant to another. The numbers of clutches and eggs as well as clutch size during December 2012 were differed significantly from food type to another. The highest numbers were noticed when $M$. cartusiana snails were fed on pea, while the lowest were noticed with carrot leaves which gave 3.2, (1. 4), 178.6 (34.8) and 55.81, (24.85), respectively. The same trend was observed during January and February 2013 where the highest numbers of clutches, eggs and clutch sizes (eggs/ clutch) were found with pea leaves, while the lowest values were observed with carrot leaves. The highest values during January and February were 2.8 (2), 155.8 (65.4) and 55.64 (32.7) for pea leaves where the lowest values were 1.2 (1.0), 31.4 (21) and 26.16 (21) for carrot leaves, respectively.

Regarding general means, it was noticed that pea resulted the highest numbers of clutches, eggs and clutch size while carrot leaves gave the lowest ones with values of 2.66 (1.2), 133.26 (29.06) and 48.05 (24.03), respectively. Generally, the efficiency of food type on the numbers of clutches and eggs could be arranged descendingly as follows: pea, lettuce, cabbage, Egyptian clover and carrot leaves, where they gave 2.66 clutches (133.26 eggs, ) 2.26 (94.33), 1.66 (64), 1.4 (44.6) and 1.2 (29.06), respectively.

When discussing the foregoing results, it was found inconstant results concerning the effect of different food types on numbers of clutches and eggs, for example Baker, (1991) and Arafa, (1997) found that the highest numbers of eggs / clutch laid by $M$. cartusiana snail were detected in the case of lettuce followed by cabbage and pea. Mohamed, (1999) reported that Eobania vermiculata snails fed on mixture food gave the highest number of eggs followed by lettuce, cucumber and potato. Mahrous, et al. (2002) found that egg lying of M. cartusiana and Helicella vestalis snails started from the beginning of December untill mid February in the next year. Lokma, (2007) reported that $M$. cartusiana gave the highest values of eggs and egg clutches when fed on lettuce leaves followed by cabbage, Egyptian clover and broad bean, descendingly. Whereas few eggs and clutches were laid when snail ware fed on pea leaves. Abed, (2011) found that $M$. cartusiana gave the highest values of number of eggs and clutches when fed on lettuce leaves followed by cabbage comparing with those recorded by pea leaves and potatoe tubers. Total number of eggs and clutches when fed on lettuce and cabbage leaves were 471.8 eggs and 21.4 clutches as well as 253 eggs and 13.6 clutches, respectively. Clutch size during the breeding season was 22 and 18.6 eggs for lettuce and cabbage leaves. The total number of eggs, clutches and clutch size when snails were fed on pea leaves and potatoes tuber were (136.2 \& 30.4 eggs), (6.6 \& 2.2 clutches) and (20.6 $\& 13.8$ as clutch size), respectively. 
Table 1. Effect of food type on numbers of clutches, eggs and clutch size of Monacha cartusiana snail under laboratory conditions.

\begin{tabular}{|c|c|c|c|c|c|c|c|c|c|c|c|c|}
\hline \multirow[b]{3}{*}{ Treatments } & \multicolumn{12}{|c|}{ Examination date } \\
\hline & \multicolumn{3}{|c|}{ December 2012} & \multicolumn{3}{|c|}{ January 2013} & \multicolumn{3}{|c|}{ February 2013} & \multicolumn{3}{|c|}{ General mean } \\
\hline & $\begin{array}{l}\text { No. of } \\
\text { clutches }\end{array}$ & $\begin{array}{c}\text { No. of } \\
\text { eggs }\end{array}$ & $\begin{array}{l}\text { Clutch } \\
\text { size }\end{array}$ & $\begin{array}{l}\text { No. of } \\
\text { clutches }\end{array}$ & $\begin{array}{c}\text { No. of } \\
\text { eggs }\end{array}$ & $\begin{array}{l}\text { Clutch } \\
\text { size }\end{array}$ & $\begin{array}{l}\text { No. of } \\
\text { clutches }\end{array}$ & $\begin{array}{c}\text { No. of } \\
\text { eggs }\end{array}$ & $\begin{array}{l}\text { Clutch } \\
\text { size }\end{array}$ & $\begin{array}{l}\text { No. of } \\
\text { clutches }\end{array}$ & $\begin{array}{l}\text { No. of } \\
\text { eggs }\end{array}$ & $\begin{array}{c}\text { Clutch } \\
\text { size }\end{array}$ \\
\hline Pea & 3.2 & 178.6 & 55.81 & 2.8 & 155.8 & 55.64 & 2 & 65.4 & 32.7 & $2.66^{\mathrm{a}}$ & $133.26^{\mathrm{a}}$ & 48.05 \\
\hline Lettuce & 2.8 & 122.4 & 43.71 & 2.4 & 110.2 & 45.91 & 1.6 & 50.4 & 31.5 & $2.26^{\mathrm{a}}$ & $94.33^{\mathrm{b}}$ & 40.37 \\
\hline Cabbage & 2.0 & 78.8 & 39.4 & 1.8 & 76.8 & 42.66 & 1.2 & 36.4 & 30.33 & $1.66^{\mathrm{b}}$ & $64^{c}$ & 37.46 \\
\hline $\begin{array}{l}\text { Egyptian } \\
\text { clover }\end{array}$ & 1.8 & 54.4 & 30.22 & 1.4 & 51.4 & 36.71 & 1.0 & 28 & 28 & $1.4^{\mathrm{bc}}$ & $44.6^{\mathrm{cd}}$ & 31.64 \\
\hline Carrot & 1.4 & 34.8 & 24.85 & $\begin{array}{l}1.2 \\
\text { L.S.I }\end{array}$ & 31.4 & 26.16 & 1.0 & 21 & 21 & $\begin{array}{l}1.2^{c} \\
0.42\end{array}$ & $\begin{array}{c}29.06^{\mathrm{d}} \\
25.13\end{array}$ & $\begin{array}{c}24.03 \\
-- \\
\end{array}$ \\
\hline
\end{tabular}

* Data in the columns followed by the same letter were not significantly different $(\mathrm{P}<05)$, according to Duncan's multiple range test.

Table 2. Effect of feeding on leaves of five plant species on growth parameters of M. cartusiana under laboratory conditions.

\begin{tabular}{|c|c|c|c|c|c|c|c|c|c|c|c|c|}
\hline \multirow[b]{2}{*}{ Plant species } & \multicolumn{2}{|c|}{ January, } & \multicolumn{2}{|c|}{ February, } & \multicolumn{2}{|c|}{ March, } & \multicolumn{2}{|c|}{ April, } & \multicolumn{2}{|c|}{ May, } & \multicolumn{2}{|c|}{ June , 2013} \\
\hline & $\begin{array}{c}\text { Weight } \\
\text { (mg) }\end{array}$ & $\begin{array}{l}\text { Shell } \\
\text { diam } \\
(\mathrm{mm})\end{array}$ & $\begin{array}{l}\text { Weight } \\
\text { (mg) }\end{array}$ & $\begin{array}{l}\text { Shell } \\
\text { diam } \\
(\mathrm{mm})\end{array}$ & $\begin{array}{c}\text { Weight } \\
\text { (mg) }\end{array}$ & $\begin{array}{l}\text { Shell } \\
\text { diam } \\
(\mathrm{mm})\end{array}$ & $\begin{array}{c}\text { Weight } \\
\text { (mg) }\end{array}$ & $\begin{array}{l}\text { Shell } \\
\text { diam } \\
(\mathrm{mm})\end{array}$ & $\begin{array}{l}\text { Weight } \\
(\mathrm{mg})\end{array}$ & $\begin{array}{l}\text { Shell } \\
\text { diam } \\
(\mathrm{mm})\end{array}$ & $\begin{array}{l}\text { Weight } \\
\text { (mg) }\end{array}$ & $\begin{array}{l}\text { Shell diam } \\
\quad(\mathrm{mm})\end{array}$ \\
\hline Pea & 2.28 & 1.4 & 4.69 & 2.24 & 13.40 & 5.52 & 40.87 & 6.56 & 119.37 & 8.51 & $200.80 \mathrm{a}$ & $11.51 \mathrm{~A}$ \\
\hline Lettuce & 2.04 & 1.02 & 3.80 & 1.79 & 11.30 & 3.82 & 31.55 & 4.31 & 90.30 & 6.39 & $173.45 b$ & $9.35 \mathrm{~B}$ \\
\hline Cabbage & 1.74 & 0.9 & 2.88 & 1.48 & 9.27 & 2.70 & 23.43 & 3.43 & 75.43 & 5.30 & $145.26 \mathrm{c}$ & $8.17 \mathrm{C}$ \\
\hline $\begin{array}{l}\text { Egyptian } \\
\text { clover }\end{array}$ & 1.32 & 0.8 & 2.59 & 1.31 & 8.25 & 2.21 & 18.7 & 3.34 & 64.38 & 4.23 & $120.35 d$ & $7.29 \mathrm{D}$ \\
\hline carrot & 1.0 & 0.72 & 2.11 & 1.24 & 6.34 & 1.86 & 12.91 & 2.26 & 49.67 & 3.21 & $94.63 \mathrm{e}$ & $6.41 \mathrm{E}$ \\
\hline
\end{tabular}

* Means in columns not followed by the same letter are significantly different at $\mathrm{P}<05$ by Duncans multiple range test 
2- Effect of feeding on leaves of five plant species on growth parameters of $M$. cartusiana under laboratory conditions.

Data presented in Table (2) showed the effect of food type on growth pattern of $M$. cartusiana as indictated by weight and shell diameter under laboratory conditions at Sharkia governorate. Results revealed that when the newly hatched juveniles of $M$. cartusiana were reared on leaves of 5 different plant species during 6 months, weight and shell diameter of snails differed significantly from one food to another. The highest values of weight $(\mathrm{mg})$ and shell diameter $(\mathrm{mm})$ were recorded with pea, during June, 2013 (200.80 \& 11.51), respectively. On the other hand, the lowest values were noticed by feeding on carrot which gave $94.63 \mathrm{mg}$ and $6.41 \mathrm{~mm}$ for weight and shell diameter, respectively.

Generally, the tested food types could be arranged descendingly according to their suitability for growth of $M$. cartusiana snails as measured by weight and shell diameter as follows: pea and lettuce were more favorable, followed by cabbage and Egyptian clover, while the lowest effect was obtained with carrot leaves.

Discussing the foregoing results, it could be concluded that variation in growth patterns (weight and shell diameter) of $M$. cartusiana snails after feeding on different food types for 6 months, may be attributed to difference in nutrient compositions of the tested foods. The present results agree to certain extent with results obtained by many authors.

For instance, Cobbinah and Osei-Nkrumah (1988) studied the growth rate of Achatina achatina as measured by snail weight and shell diameter. The four tested food stuffs were arranged for their suitability as follows: green pawpaw (Carica popaya), cocoyum leaves (Xanthosoma mafaffa), flam flower leaves (Taliman triangolare) and ripe palm fruits (Elaeis guineansis). Arafa (1997) found that the highest values of weight of Monacha sp. increment were recorded during spring months. On the other hand, leaves of sweet pea gave the highest weight average / month followed by lettuce while cabbage leaves were the lowest one. Ismail (1997) reported that leaves of lettuce and cabbage were more favorable for $M$. cartusiana snails followed by broad bean and Egyptian clover, while navel orange was the lowest one in this respect. Ismail, (2004) reported the five tested plant leaves and potato tubers could be arranged descendingly according to their effect on growth of E. vermiculata that measured by shell diameter as follows: potato slices, lettuce and cabbage leaves were more favorable, followed by navel orange leaves, while the lowest effect was obtained with banana and mango leaves. Finally, Abed, (2011) found that when juveniles of $M$. cartusiana snails were maintained on soil containing $4 \%$ of $\mathrm{CaCO}_{3}$ gave the highest shell diameter and body weight $(3.7 \mathrm{~mm}$ and $26.3 \mathrm{mg}$ ), respectively. Regarding snail maintained on soil containing $8 \%$ and $2 \% \mathrm{CaCo}_{3}$, the shell diameter were 3.49 and 2.67 $\mathrm{mm}$, respectively while body weight were 23.4 and $9.6 \mathrm{mg}$ respectively. The lowest shell diameter and body weight were recorded in juveniles maintained on soil free from $\mathrm{CaCo}_{3}$, those where recorded 2.6 $\mathrm{mm}$ and $7.1 \mathrm{mg}$, respectively.

\section{References}

Abed, M. (2011). Biological studies on land snail Monacha cartusiana in Sharkia and Monoufia Governorates. M.Sc. Thesis, Fac. Sci., Al-Azhar Univ., $110 \mathrm{pp}$.

Arafa, A.A.I. (1997). Studies on some land molluscs at Sharkia Governorate M.Sc. Thesis, Fac. Agric. Al- Azhar Univ. 137 pp.

Asran, F.D. (1994). Studies on harmful terrestrial snails and their management on Egyptian agricultural lands. M.Sc. Thesis, Insitit. Environ. Study \& Res. Ain Shams Univ., Cairo. 125 pp.

Baker, G. H. (1991). Production of eggs and young snails by adult of Theba pisana (Muller) and Cernuella virgata (Decosta) (Mollusca: Helicidae) in the laboratory clutches and field popultions. Australian, J. Zool., 39:673- 679.

Barker, G. M. (2002). Molluscs as crop pests (CAP International walling Forti Dxon) 10 DE. V. K. 468 pp.

Cobbinab, J.R. and Osei- Nkrumah, A. (1988). The effect of food on growth of Achatina achatina. Snail farming Res. 2: $20-24$

Duncan, D. B. (1955). Multiple range and multiple F tests. Biometric, 11: 1-42.

El- Masry, S. A. (1997). Studies on the control of some land snails infesting certain fruit trees. $\mathrm{Ph}$. D. Thesis, Fac, Agric. Zagazig Univ., 150 pp.

El-Okda, M.M.K (1980). Land snails of economic importance on vegetable crops at Alexandria and neighboring region. Agric. Res. Rev., 58 (1): $79-$ 85.

El-Okda, M.M.K (1981). Response of two land mollusca to certain insecticides.Bull. Ent. Soc. Egypt. Econ. Ser. 12 pp 53-57

Godan, D. (1983). Pest slugs and snails, biology and control. Springer- Verlag Berlin, Heidelberg, 445 pp.

Ismail, Sh.A. (1997). Ecology, biology and control of certain terrestrial snails infesting some vegetable and field crops in Sharkia Governorate. Ph.D. Thesis, Fac. Agric., Zagazig Univ. 128 pp.

Ismail, Sh.A.A. (2004). Ecobiological studies on the brown garden snail, Eobania vermiculata Muller under laboratory and field conditions in Sharkia Governorate. Zagaizg J. Agric. Res., 31 (1): 293 -305 .

Lokma, M.H.E. (2007). Studies on some terrestrial gastropods injurious to field crops at Sharkia Governorate. M. Sc. Thesis, Fac. Agric., Zagazig Univ., 147 pp. 
Lokma, M.H.E. (2013). Studies on some terrestrial molluscs injurious to vegetables and field crops in East Delta locality (Sharkia and Ismalia). Ph.D. Thesis, Fac. Agric. Moshtohor, Benha Univ., 179 pp.

Mohamed, M. F. (1999). Ecological and biological studies on land snails and slugs in Egypt. PH. D. Thesis, Fac. Agric., Cairo Univ., 170 pp.

Mahrous, M. E.; Ibrahim Mervat, H. and Abd ElAal, E. M. (2002): Ecobiological aspects of the glassy clover snail, Monacha cartusiana (Muller) under field condtions in Sharkia Governrate,
Egypt. 2 nd Inter. Conf. Plant, Protec. Res. Instit. Cairo., 1: 107- 114.

Nakhla, J.M. and Tadros, A.W. (1995). Studies on the seasonal abundance of land snails on date palm shoots in Sharkia Governorate. Egypt. J. Res., 73 (2): 347 - 355.

Staikou. A. and Lazaridou- Dimitriadou, M. (1989). Feeding experiments and energy flux in a natural population of the edible snails Helix lucorum (L.) (Gastropoda: Pulmonata: Stylommatophora) in Greece. Malacologia, 31 (1): $217-227$. 


\title{
تاثير نوع الغذاء علي بعض النواحي البيولوجية لقوقع موناكا كارتوسيانا تحت الظروف المعملية
}

\author{
عبدالحق عبدالحق إبراهيم عرفة \\ معهذ بحوث وقاية النباتات- مركز البحوث الزراعية- الدقي- جيزة- مصر
}

أجريت هذه الدراسة بهدف معرفة تاثير خمس انواع من الغذاء وهي اوراق نباتات البسلة - الخس- الكرنب- البرسيم المصري- اوراق الجزر

علي بعض النواحي البيولوجية لقوقع البرسيم الزجاجي (موناكا كارتوسيانا) معطليا- اتضح أن لنوع الغذاء تاثير معنوي علي عدد كتل البيض وكذا لهاء عدد البيض و حجم الكتلة كما أثنارت الدراسة ان التغذية علي اوراق البسلة اعطي اعلي معدل من كتل البيض وعدد البيض حيث كان المتوسط العام 2.66 كتلة و 133.26 بيضة بمعدل 48.5 بيضة/ كتلة بينما كانت أقل معدل مع اوراق الجزر حيث كانت القيم 1.2 كتلة - 29.6 بيضة بمعدل 24.03 بيضة/ كتلة. أما بخصوص تاثير نوع الغذاء علي نمو قوقع موناكا كارتوسيانا فقد اوضحت الدراسة ان البسلة اعطت اعلي معدل للنمو بينما أدت التخذية علي اوراق الجزر اقل معدل للنمو ويمكن ترنيب النباتات المختبرة تتازليا طبقا لناثيرها علي النمو كما يلي: البسلة -الخس فأنس الكرنب البرسيم المصري ثم الجزر في المرتبة الاخيرة. 